\title{
We Will Always Have International Law: Editorial Note
}

Martins Paparinskis*

Casablanca opens with a shot of a revolving globe. ${ }^{1}$ The intention, as the producer of the movie explained, was 'to have a spinning globe - an unusual, interesting shot, sketchily lighted', 'immediately preceding the montage of the refugees'. ${ }^{2}$ Before the camera zooms in to the refugee trail starting in Paris, it shows the political map of Europe, which - as a careful eye might spot -also includes the boundaries of Estonia, Latvia, and Lithuania. Baltic States do not play a major (or indeed any) role in the movie, but a watcher familiar with the history of international relations might pause and wonder about the cartographic solution. The demarcated presence of the three Baltic States on the world map of December 1941 - when the story of Casablanca unfolds - is not an obvious choice. These States had been effectively annexed by the Soviet Union in 1940, ${ }^{3}$ and in 1941 were under the effective control of the German Reich. Why, then, are they still on the map?

An international lawyer, if one were available to discuss the pedantic minutiae, would likely explain the presence of the Baltic States as an application of the more general proposition that illegal annexation does not affect the existence of the State under international law ${ }^{4}$ (or, to use the modern State responsibility parlance, third States are under an obligation not to recognize as lawful a situation created by the breach of a jus cogens rule $\left.{ }^{5}\right)$. In short, it does not matter that all or nearly all manifestations of the Baltic States disappeared: ${ }^{6}$ the pristine legal proposition is unaffected by the mundane unlawfulness of everyday practice. In Casablanca, the substance of this point is articulated by Viktor Lazlo: when Major Strasser remarks to him that

\footnotetext{
* Reader in Public International Law, University College London, Faculty of Laws.

1 Casablanca (Warner Bros., 23 January 1943), <http://www.imdb.com/title/tt0034583/> accessed 1 September 2017.

${ }^{2}$ N Isenberg, We'll Always Have Casablanca: The Life, Legend, and Afterlife of Hollywood's Most Beloved Movie (2017) 131.

$3 \mathrm{~J}$ Crawford, The Creation of States in International Law (2 $2^{\text {nd }}$ ed 2007) 703.

4 Ibid, 689-90. I am not arguing that the map of Casablanca was crafted with such a legal proposition in mind: my (admittedly superficial) research of the issue suggests that the key political point was the Nazi threat across the globe, Isenberg (n 2) 101-2, 129-133 (the director of the opening montage does not mention it in his autobiography, D Siegel, Don Siegel: A Siegel Film (1993) 75). It would be interesting to explore, still, whether the US public position on non-recognition of annexation of Baltic States, <http://digitalarchive.wilsoncenter.org/collection/279/unitedstates-non-recognition-policy> accessed 1 September 2017, had any trickle-down effect here.

52001 ILC Articles on State responsibility art 41(2); Jurisdictional Immunities of the State (Germany v Italy: Greece intervening) [2012] ICJ Rep 99, para 93.

${ }^{6}$ Crawford (n 3), 690.
} 
'You were a Czechoslovakian. Now you are a subject of the German Reich!', Lazlo responds that 'I've never accepted that privilege'.

The Lazlo approach of speaking the truth (of international law) to power is an attractive and powerful way of conceiving the professional role of international lawyers. ${ }^{7}$ It is often accompanied by anecdotes of how international law shapes and directs international power $(\mathrm{s})^{8}-$ speaking the truth may be its own reward, but it does feel nice if, in addition, it also matters in that elusive place 'the real world'. Judge James Crawford, one of the participants in the opening discussion of the 2016 European Society of International Law Riga Conference, points to East Timor as an example of a case where international law contributed to persistence of disputes and their eventual resolution against the interests of the powerful. ${ }^{9}$ With a nod to the possibility of projection, this framing of international law, as both important and benign, has a powerful influence on Baltic international lawyers, with the recent example of restoration of statehood before their eyes. ${ }^{10}$ Upon this reading, international law did (eventually) deliver on its promise, perhaps even more impressively than for East Timor, since the effective control of Baltic States by other States was twice as lengthy as for East Timor, and practice of non-recognition could not be anchored within the structure of the United Nations. (Some will say that this success was due to the almost complete lack of practical effect to the question of whether the post-1991 Baltic States continued the identity of the pre-1940 Baltic States ${ }^{11}$-- unlike the case of East Timor ${ }^{12}$-but that is a discussion for another day.)

The Lazlo effect on the Baltic States' practice is less clear cut in the more contemporary regimes of international law. One school of thought in policy-making, perhaps somewhat influenced by the normative considerations sketched above, suggests that serious engagement with international law and institutions is the right thing and the smart thing for States like Baltic

\footnotetext{
7 Cf. D Kennedy, 'Speaking Law to Power: International Law and Foreign Policy: Closing Remarks' (2005) 23 Wisconsin International Law Journal 173; J Crawford, 'International Law as Discipline and Profession' (2012) 106 ASIL Proceedings 471, 485.

8 E.g. the effect of the Alabama arbitration on the conflict between the US and Great Britain was somewhat exaggerated, leading to unrealistic expectations about the potential of international dispute settlement in, D Caron, 'War and International Adjudication: Reflections on the 1899 Peace Conference' (2000) 94 AJIL 4, 9; VV Veeder, 'The Historical Keystone to International Arbitration: The Party-Appointed Arbitrator-From Miami to Geneva' in D Caron et al (eds), Practicing Virtue: Inside International Arbitration (2015) 127, 147-9; see (1872) 29 RIAA 125.

9 J Crawford, 'Chance, Order, Change: The Course of International Law' (2013) 365 Hague Recueil 9, 43-6.

${ }_{10}$ It is also plausible to expect that this perception will become stronger with the passage of time, as the new generations of international lawyers increasingly view the restoration as necessity, rather than contingency; on the concepts see S Marks, 'False Contingency' (2009) 62 Current Legal Problems 1.

${ }^{11} \mathrm{~J}$ Crawford and A Boyle, 'Opinion: Referendum on the Independence of Scotland - International Law Aspects' $(10$

December

<https://www.gov.uk/government/uploads/system/uploads/attachment_data/file/79408/Annex_A.pdf> accessed 1 September 2017 para 103.

12 See various disputes between East Timor and Australia in the Permanent Court of Arbitration, <https://pcacases.com/web/allcases/> accessed 1 September 2017.
} 
States. For example, weaker participants in international dispute settlement will generally benefit from having access to more formalised dispute settlement through arbitration and judicial settlement, which would have direct influence on the type of arguments that have relevance in dispute settlement and also indirectly influence less formal dispute settlement mechanism by throwing the shadow of law. More generally, Baltic States could have a strategic interest in promotion of (in various jargons) greater institutionalisation of international rule of law and normative power.

Another way of reading Baltic States' engagement with international law by reference to Casablanca would, if tongue in cheek, rather emphasise the pursuit of goals of various degrees of merit through imperfect institutions: here, Captain Louis Renault is a better metaphor, with Baltic States acting not worse than others but certainly not better (whether normatively or in terms of competence) either. A superficial look cast by some at decisions in relation to Baltic States that emerge from various judicial and quasi-judicial bodies would not find any obvious differences in the attitude by these States to, and involvement with international law, if compared to other States in this and other regions. Indeed, contemporary refugee trails do not appear to have put the Baltic States at the forefront of humanitarian engagement. Perhaps inescapably, it is harder to maintain the purity of the principled argument when one has carry out the job of governance and expertise. ${ }^{13}$

There is one particular point, though, on which the international law practice of Baltic States (or at least of Latvia, with which I am more familiar) is markedly more enlightened than is commonly the case, and it relates to gender diversity in international courts and tribunals. Within contemporary international law, international judges and other comparable decision-makers play an increasingly important role, and gender diversity has been identified as one element of their institutional legitimacy (Casablanca provides a useful contrast here of deeply problematic assumptions about female agency; Ilsa Lunde's role is basically that of a helpmate to a great man, and the movie's real question is: which great man $\left.{ }^{14}\right)$. The law and policy of gender diversity in international adjudication has been the subject to sophisticated debates in recent years, in relation to institutionalised courts, ad hoc dispute settlers, as well as monitoring institutions. In Latvian practice, gender-diverse nominations and appointments have been made to the International Criminal Court, the Human Rights Committee, the Working Group on Arbitrary Detention, the Permanent Court of Arbitration, ICSID Panel of Arbitrators, the General Court of the European

\footnotetext{
${ }^{13} \mathrm{D}$ Kennedy, A World of Struggle: How Power, Law and Expertise Shape Global Political Economy (2016).

14 R Ebert, 'Casablanca' (1996) < http://www.rogerebert.com/reviews/great-movie-casablanca-1942> accessed 1 September 2017. Cf. Barcelona Traction, Light and Power Company, Limited (Belgium v Spain) (New Application: 1962) [1970] ICJ Rep 3, Separate Opinion of Judge Sir Gerald Fitzmaurice 64 fn 23.
} 
Union, the European Court of Human Rights, the European Committee of Social Rights, the European Commission against Racism and Intolerance, and in investor-State treaty arbitration (indeed, the only obvious gap so far is the Court of Justice of the European Union). It may be of interest to explore the institutional and normative reasons for why Latvia has become a positive outlier in this field, and the extent to which Latvian experience is transposable elsewhere.

Is there a common and consistent thread to these observations? Perhaps not --- but the ambiguity itself is a useful frame of reference for reading (Baltic/European) perspectives of international law, where broader normative idealism intersects with strategic promotion of (particular institutions of) the rule of law, mundane compromises and shortcuts, and unexpected glimpses of enlightenment. That is exactly how international law works. The papers in this symposium quite fittingly consider European challenges to two classic general international law questions. Enrico Milano picks one of the great topics of general international law and analyses the role that international law in the 21 st century can play regarding territorial conflicts and disputes in Europe. While noting the undoubted importance of international law in this area, Milano calls for (what one might describe as) enlightened modesty about the role of law, and proposes a sophisticated analytical framework that distinguishes between resistance and stability; adaptation and change; and silence and neutrality. Przemyslaw Tacik addresses another classic topic - the law of international responsibility - and situates it within the framework of relationship between the European Union and the European Court of Human Rights, where he identifies genuinely new contributions to law of responsibility. To conclude, perhaps the modest broader point of the editorial note, reflected in the contributions to the symposium, is this: not everything in the world turns upon international law (nor should it ${ }^{15}$ ) -- but the role of law in setting the broader systemic assumptions and providing the vocabulary for articulating the small(er) print should not be understated either. ${ }^{16}$

15 V Lowe, 'The Limits of the Law' (2016) 379 Hague Recueil 21.

${ }^{16}$ F Berman, 'Why Do We Need a Law of Treaties' (2017) 385 Hague Recueil 17. 